\title{
ESTABELECIMENTO IN VITRO DE DUAS ESPÉCIES DE BAMBU: Dendrocalamus asper (Schultes f.) Backer ex Heyne E Bambusa oldhamii Munro
}

Cris Hanny Pires Araujo ${ }^{1}$, Luciano Lajovic Carneiro ${ }^{2}$, Cristhian Lorraine Pires Araujo ${ }^{3}$, Sérgio Tadeu Sibov ${ }^{4}$

1 Graduada em Biotecnologia pela Universidade Federal de Goiás (crishannyp@gmail.com) Goiânia-Brasil

2 Doutor em Genética e Melhoramento de Plantas pela Universidade Federal de Goiás

3 Mestranda em Produção Vegetal pela Universidade Federal de Goiás 4 Professor Doutor do Instituto de Ciências Biológicas da Universidade Federal de Goiás

Recebido em: 08/09/2015 - Aprovado em: 14/11/2015 - Publicado em: 01/12/2015 DOI: http://dx.doi.org/10.18677/Enciclopedia_Biosfera_2015_151

\section{RESUMO}

O bambu tem importância econômica em diversas áreas como construção civil, confecção de papel, fonte de energia, indústria alimentícia, mobiliário, etc. A obtenção de mudas é a principal dificuldade para o cultivo em larga escala, o cultivo in vitro torna-se uma das possíveis ferramentas para resolver o problema. Vários protocolos já foram estabelecidos para diversas espécies de bambus. Porém, os protocolos de multiplicação in vitro existentes não são reprodutíveis entre espécies diferentes. Objetivou-se o desenvolvimento de um protocolo de estabelecimento in vitro para multiplicação específica de duas espécies de importância econômica, Dendrocalamus asper (Schultes f.) Backer ex Heyne e Bambusa oldhamii Munro, de forma a eliminar ou reduzir o surgimento de microrganismos que impedem o cultivo e multiplicação in vitro. Foram testados métodos de descontaminação com e sem antibiótico e os efeitos da adição de citocininas sobre a brotação dos explantes provenientes de segmentos nodais, em meio de cultura MS (MURASHIGE \& SKOOG, 1962). A porcentagem de descontaminação dos explantes submetidos ao processo de assepsia variou entre as espécies analisadas, como observado para explantes de $D$. asper, que apresentaram maior porcentagem de contaminação microbiana. Comparando a porcentagem de contaminação entre os dois tratamentos de $B$. oldhamii, com e sem antibiótico, verificou-se que o uso da estreptomicina foi eficaz, reduzindo a ocorrência de bactérias em 38,05\%. Embora o uso da estreptomicina não interfira no número de brotos emitidos, novos experimentos devem ser feitos para verificar a maior proliferação fúngica constatada durante os experimentos após o uso de antibióticos.

PALAVRAS-CHAVE: cultura de tecidos, micropropagação, produção de mudas 


\title{
IN VITRO ESTABLISHMENT OF TWO SPECIES OF BAMBOO: Dendrocalamus asper (Schultes f.) Backer ex Heyne and Bambusa oldhamii Munro
}

\begin{abstract}
Bamboo has economic importance in many areas such as construction, manufacturing paper, energy supply, food industry, furniture, etc. Getting seedling is the main difficulty for the large-scale cultivation, in vitro culture becomes the most appropriate tool to resolve the issue. Several protocols have been established for many species of bamboo. However, the known protocols are not reproducible for different species. The aim was development of protocol for in vitro establishment and multiplication of two species with economic importance, Dendrocalamus asper (Schultes f.) Backer ex Heyne e Bambusa oldhamii Munro, to eliminate or reduce the microorganism that affect cultivation and in vitro multiplication. Decontamination methods were tested with or without antibiotic and the cytokinins effect on explant shoots from nodal segments on MS medium (MURASHIGE e SKOOG, 1962). The percentage of decontamination of explants subjected to aseptic process varied between the two species analyzed. Explants of $D$. asper had higher percentage of contamination. By comparing the percentage of contamination between the two treatments $B$. oldhamii, with or without antibiotic, was finding that use of streptomycin was effective in reducing $38.05 \%$ of bacterial contamination. Although the use of streptomycin does not interfere in the number of issued shoots, new experiments should be done to check the increase in the fungal contamination found during the experiments.
\end{abstract}

KEYWORDS: micropropagation, seedling production, tissue culture

\section{INTRODUÇÃO}

Bambus são plantas pertencentes à subfamília Bambusoideae, da família Poaceae (SINGH et al., 2011). Possuem aproximadamente 45 gêneros e mais de 1.300 espécies espalhadas pelo mundo, localizadas na sua maior parte na Ásia e na América e, em menor número, na África e Oceania. Na Europa, não são encontradas espécies nativas. Os bambus são distinguidos pela presença de colmos, complexa ramificação, presença de um sistema de rizomas robusto e floração infrequente. No Brasil, foram catalogadas cerca de 100 espécies, tanto nativas como exógenas (SALGADO, 2014).

No mundo, as florestas de bambu cobrem uma área de 14 milhões de hectares (EMBAYE, 2003 apud SALGADO, 2014) e geram comércio mundial da ordem de U\$ 4,5 bilhões (CAMPOS et al., 2003 citado por SALGADO, 2014). Esta planta apresenta uma grande diversidade de usos como na construção civil, confecção de papel, na área alimentícia, dentre outras. O centro de pesquisas China Bamboo Research Center - CNBRC destacou que houve crescente uso do bambu desde os anos 1980, em diversas áreas industriais, além de aplicações em engenharia e química. Produtos a base de bambu processado podem substituir, ou até mesmo evitar, o corte e o uso predatório de florestas tropicais (CORREIA, 2011).

O bambu é, há muito tempo, propagado vegetativamente através de técnicas como desdobramento de touceiras, enraizamento de estacas ou pedaços de colmos e ramos (FRANÇA, 2011). A propagação em larga escala utilizando os métodos convencionais requer o uso de muitas matrizes, não sendo um método viável de produção. Considerando-se a importância de produzir e disponibilizar grande 
número de material de plantio, uma alternativa para a produção em grande escala é a micropropagação.

A obtenção de matéria-prima padronizada para um mercado cada vez mais exigente por quantidade e padrão de qualidade adequada é um dos principais desafios para o cultivo do bambu em larga escala. O ideal é a obtenção de plantas com homogeneidade genética para facilitar seu manejo e viabilizar a produção comercial. Uma das formas de se obter a homogeneidade é propagar genótipos elite de forma vegetativa (ALMEIDA et al., 2013).

A propagação de mudas de bambu in vitro é uma alternativa ao processo convencional de propagação vegetativa por meio de touceiras, rizomas ou colmos. Nas técnicas empregadas na cultura de tecidos vegetais, pequenos fragmentos de tecido vivo, chamados explantes, são isolados de um organismo vegetal, descontaminados e cultivados assepticamente por períodos definidos em um meio de cultura apropriado (ANDRADE, 2002). O método é usado para obter novas plantas geneticamente idênticas à original, realizar a clonagem vegetal que é definida como a propagação assexuada de células ou organismos, de modo a obter novos indivíduos, mantendo-se o genótipo idêntico àquele do ancestral comum (CALDAS et al., 1998). O material então regenerado pode ser submetido a diversos testes, a fim de se verificar em quais condições se desenvolve melhor.

A contaminação microbiana que ocorre durante a propagação in vitro de plantas é um grande gargalo que impede a experimentação bem sucedida e o estabelecimento de processos de assepsia adequados para cada cultura. Procedimentos experimentais que incluem a esterilização química e uso de antibióticos foram utilizados em vários níveis de sucesso para minimizar ou eliminar a contaminação (NADHA et al., 2012).

A ocorrência de bactérias em culturas de tecido de bambu já foi relatada na literatura para diversas espécies como Guadua angustifolia Kunth (NADHA et al., 2012), Fargesia rufa, Phyllostachys humilis, Phyllostachys nigra, Phyllostachys atrovaginata (MOSYNETS, 2012). De acordo com NADHA e colaboradores (2012), esta tem sido a causa da queda no desempenho de culturas, da degeneração de longo prazo dos estoques mantidos, e da dificuldade de reprodutibilidade de protocolos de cultura de tecidos.

Microrganismos endófitos desempenham um papel especial na planta em relação a adaptação ao estresse, devido à sua particular parceria estrutural e funcional com a planta (THOMAS et al., 2007; PIRTILLA et al., 2008; COMPANT et al., 2010). De acordo com MOSHYNETS (2012), é importante o conhecimento da microbiota associada à espécies de bambu para que se possa ter conhecimento dos efeitos de determinados antibióticos em várias dessas bactérias sem afetar negativamente o material vegetal cultivado in vitro.

Em função da falta de informações para a propagação de mudas em larga escala de Dendrocalamus asper e Bambusa oldhamii no Brasil, esse trabalho tem por objetivo desenvolver protocolos de estabelecimento in vitro para micropropagação específica de duas espécies de importância econômica, de forma a eliminar ou reduzir o surgimento de microrganismos que impedem o cultivo e multiplicação in vitro. 


\section{MATERIAL E MÉTODOS}

\section{Coleta de material a campo}

Foram utilizados, como explantes, segmentos nodais de plantas matrizes de D. asper e B. oldhamii provenientes da Coleção de Espécies de Bambu da Escola de Agronomia da Universidade Federal de Goiás, Goiânia, GO. Foram consideradas plantas matrizes aquelas que apresentaram boas condições fisiológicas e sanitárias, estando vigorosas e isentas de qualquer tipo de estresse. Os explantes de D.asper e $B$. oldhamii descontaminados sem o uso de antibiótico foram coletados em 12/08/2014 já os explantes de B.oldhamii submetidos ao processo de assepsia com uso de antibiótico foram coletados em 10/09/2014.

\section{Descontaminação dos explantes sem antibiótico}

O experimento foi conduzido com objetivo de definir um protocolo inicial de assepsia dos explantes meristemáticos (gemas). No Laboratório de Cultura de Tecidos Vegetais foi realizada a descontaminação de cada espécie separadamente através da limpeza inicial dos segmentos nodais (colmos) de $D$. asper e B. oldhamii coletados, com auxílio de algodão embebido em álcool $70 \%$ (v/v). Cada colmo foi submetido ao processo de limpeza por três vezes trocando o algodão em cada etapa. Em seguida, os explantes foram acondicionados em um frasco com $50 \mathrm{~mL}$ de água, envolvidos com filme de PVC e levados à geladeira, onde ficaram por um período de 24 horas. $\mathrm{Na}$ câmara de fluxo laminar os explantes passaram por diferentes etapas de assepsia. Primeiramente, submetidos à agitação manual por 1 min. em um frasco com álcool $70 \%(\mathrm{v} / \mathrm{v})$. Em outro frasco contendo hipoclorito de sódio ( $\mathrm{NaClO}$ ) 2,0\% de cloro ativo ( $\mathrm{v} / \mathrm{v}$ ) com duas gotas de detergente comum, foram agitados por $15 \mathrm{~min}$. Seguido de três enxágues em água destilada e autoclavada. $\mathrm{O}$ próximo passo consistiu em agitar as amostras em um frasco contendo $\mathrm{NaClO}$ $1,25 \%$ de cloro ativo ( $\mathrm{v} / \mathrm{v})$ durante $5 \mathrm{~min}$. A descontaminação foi finalizada com cinco lavagens sucessivas em água destilada e autoclavada.

\section{Descontaminação dos explantes com antibiótico}

Foi realizada a descontaminação através da limpeza inicial dos segmentos nodais de $B$. oldhamii coletados, com auxílio de algodão e álcool $70 \%$ (v/v), cada colmo foi submetido ao processo de limpeza por três vezes trocando o algodão em cada etapa, seguido de imersão em álcool $70 \%(\mathrm{v} / \mathrm{v})$ por $1 \mathrm{~min}$., enxaguados duas vezes com água destilada autoclavada e transferidos para um Becker com $1 \mathrm{~L}$ de uma solução contendo $1 \mathrm{~g} / \mathrm{L}$ de estreptomicina mantido em agitador magnético por 60 min. Em seguida, o material foi submetido a dois enxágues em água destilada autoclavada e emergidos em $\mathrm{NaClO} 2,0 \%$ (v/v) com duas gotas de detergente comum por 15 min., seguido de imersão em $\mathrm{NaClO}$ 1,25\% (v/v) por 5 min. com duas gotas de detergente comum e cinco enxágues em água destilada autoclavada.

\section{Cultivo em meio MS semissólido}

A introdução dos explantes em meio de cultura sucede a assepsia e foi feita em câmara de fluxo laminar, em ambiente asséptico. Primeiramente, foi feito o corte do explante em tamanho padronizado $(5 \mathrm{~cm})$ para os experimentos deste trabalho, deixando a gema na porção central do segmento. A literatura científica apresenta tamanhos de explante variando de $1 \mathrm{~cm}$ à $5 \mathrm{~cm}$ dependendo da espécie utilizada e de condições específicas (DEVI \& SHARMA, 2009; LIN et al., 2007),. A bainha que protege a gema foi removida com auxílio de um alicate de cutícula esterilizado (Figura 1). Em seguida, o explante foi colocado em frascos de vidro $(300 \mathrm{~mL})$, ENCICLOPÉDIA BIOSFERA, Centro Científico Conhecer - Goiânia, v.11 n.22; p.1175 
contendo $40 \mathrm{~mL}$ de meio MS (MURASHIGE \& SKOOG, 1962) modificado com adição de $3 \mathrm{mg} / \mathrm{L}$ de 6-Benzilaminopurina (BAP) e $0,5 \mathrm{mg} / \mathrm{L}$ de Cinetina (KIN), solidificado com ágar $(6,0 \mathrm{~g} / \mathrm{L})$, com pH ajustado para 5,8 e autoclavado a $120^{\circ} \mathrm{C}$ por $20 \mathrm{~min}$. Os explantes em frascos de cultivo foram mantidos em sala de crescimento com temperatura de $25 \pm 1^{\circ} \mathrm{C}$ em intensidade luminosa de $40-45 \mu \mathrm{mol} \cdot \mathrm{m}^{-2} . \mathrm{s}^{-1} \mathrm{e}$ fotoperíodo de $16 \mathrm{~h}$. Foram utilizados 38 explantes de $B$. oldhamii e 26 de $D$. asper que passaram pelo processo de descontaminação sem antibiótico e 38 explantes de B. oldhamii que foram submetidos ao tratamento com estreptomicina.

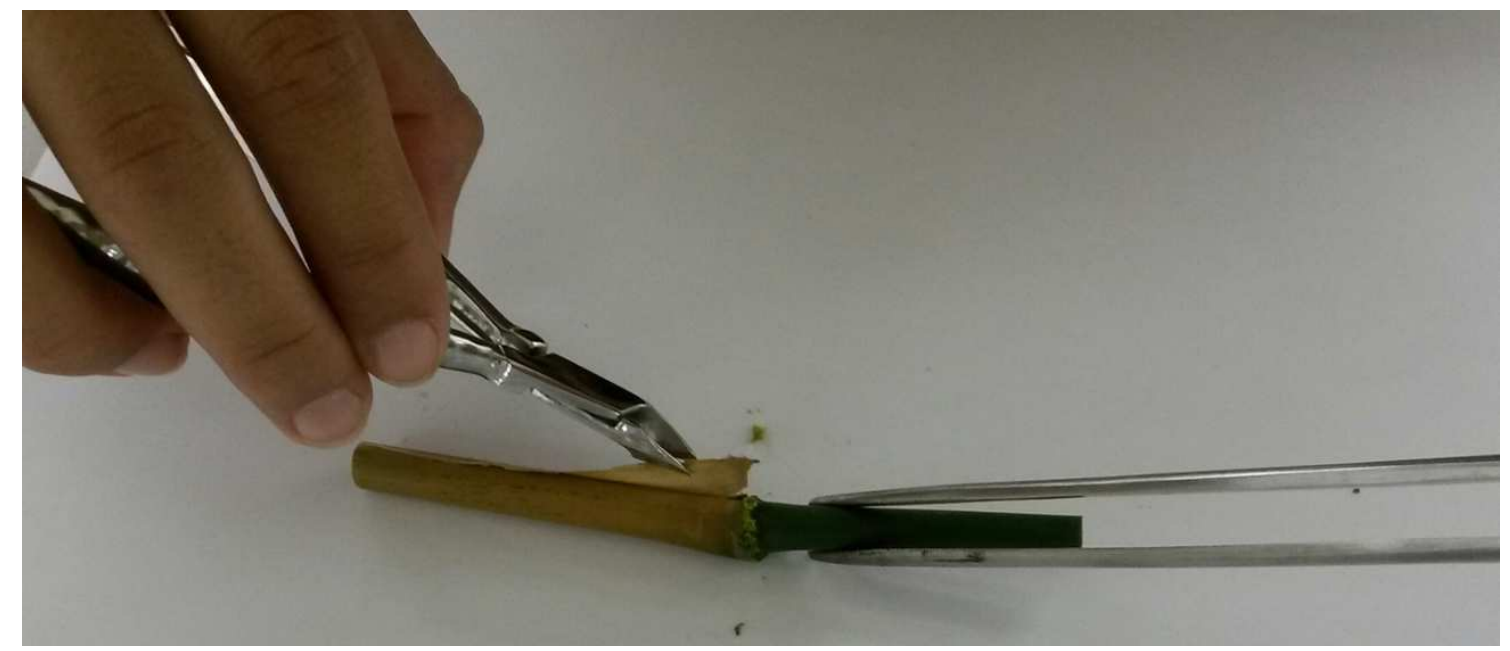

FIGURA 1 Preparação dos explantes. Corte do explante em tamanho padronizado $(5 \mathrm{~cm})$, deixando a gema na porção central do segmento. Remoção da bainha foliar que protege a gema axilar do bambu com auxílio de alicate de cutícula.

\section{Inoculação em meio MS líquido}

Foram transferidos para meio MS líquido 18 explantes de $B$. oldhamii submetidos ao tratamento de descontaminação sem antibiótico após atingirem 20 dias de inoculados em meio MS semissólido. Os explantes foram seccionados, separando os brotos do colmo, e colocados em tubos de ensaio contendo $10 \mathrm{~mL}$ de meio MS (MURASHIGE \& SKOOG, 1962) modificado com adição de $3 \mathrm{mg} / \mathrm{L}$ de BAP e $0,5 \mathrm{mg} / \mathrm{L}$ de $\mathrm{KIN}$. O pH foi ajustado para 5,8 e os tubos autoclavados a $120^{\circ} \mathrm{C}$ por 20 min. Após a inoculação os explantes foram mantidos em sala de crescimento com temperatura de $25 \pm 1{ }^{\circ} \mathrm{C}$ em intensidade luminosa de $40-45 \mu \mathrm{mol} \cdot \mathrm{m}^{-2} \cdot \mathrm{s}^{-1} \mathrm{e}$ fotoperíodo de $16 \mathrm{~h}$.

\section{Análise estatística}

A cada três dia, durante 28 dias, foi avaliada a porcentagem de emissão de brotos e de contaminação dos explantes conforme o tipo ocorrido (fúngica ou bacteriana) determinada visualmente para os explantes inoculados em meio semissólido por características específicas: bacteriana aspecto leitoso ou translucido do meio de cultura com ou sem coloração diferenciada, e fúngica pela presença de esporos ou crescimento de micélios independente da coloração (SCHERWINSKIPEREIRA, 2010). Para os explantes em meio líquido foram avaliados: emissão média de brotos e altura média dos brotos emitidos. $\mathrm{O}$ delineamento experimental escolhido foi o inteiramente casualizado. Os resultados de altura e emissão de brotos foram submetidos à comparação de médias pelo teste T de Student e nível de significância de $5 \%$. 


\section{RESULTADOS E DISCUSSÕES}

Com relação ao número de brotos, $B$. oldhamii submetido ao tratamento de descontaminação sem antibiótico produziu em média o dobro de brotos $(2,44)$ (Figura 2) quando comparado ao $D$. asper $(1,23)$, sendo esta diferença significativa $(\mathrm{t}=2,217 ; \mathrm{p}=0,0302)$ (Tabela 1). Este resultado é importante por mostrar que a emissão de brotos pode variar de uma espécie para outra, mesmo submetidos às mesmas condições de cultivo.

TABELA 1 Média da emissão de brotos para duas espécies de bambu após 28 dias de estabelecimento in vitro.

\begin{tabular}{lrc}
\hline \multicolumn{1}{c}{ Espécie } & Número de brotos * \\
\hline Bambusa oldhamii & 2,44 & $\mathrm{a}$ \\
Dendrocalamus asper & $1,23 \quad \mathrm{~b}$ \\
\hline * Média do número de brotos seguida de letras distintas \\
indicam diferença estatística significativa à $5 \%(\mathrm{p}<0,05)$.
\end{tabular}

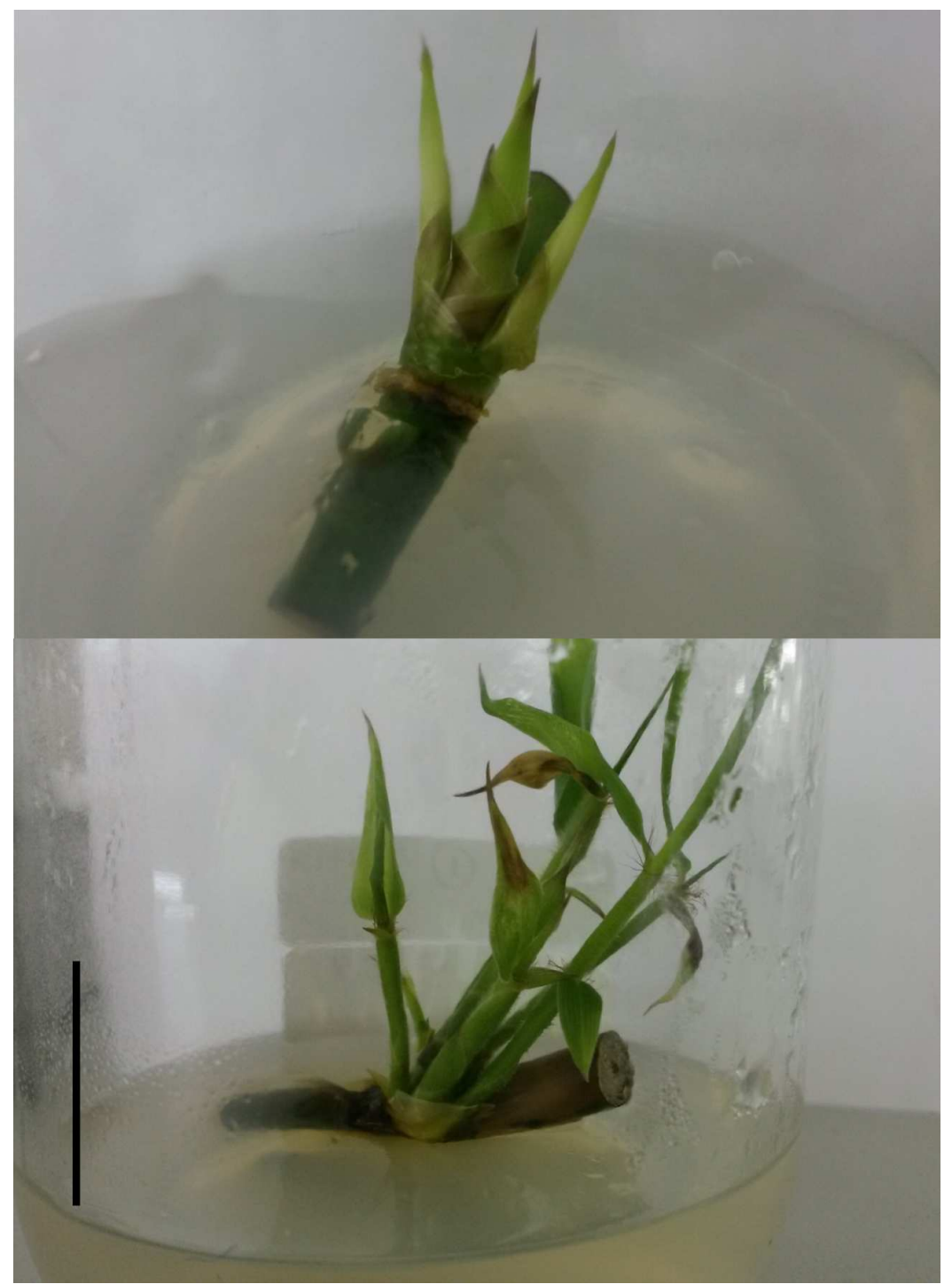

FIGURA 2 Gemas laterais de Bambusa oldhamii inoculadas em meio MS semissólido suplementado com BAP e KIN, sob fotoperíodo de 16 horas e temperatura de $25 \pm 1^{\circ} \mathrm{C}$. Imagem superior com cinco dias de cultivo e inferior com 23 dias. Barra $=4 \mathrm{~cm}$. 
As médias de emissão de brotos entre os explantes de $B$. oldhamii tratados com antibiótico $(2,42)$ e sem antibiótico $(2,44)$ não apresentaram_diferença significativa ( $t=0,053 ; p=0,9575)$, sugerindo que $o$ uso da estreptomicina não interfere no número de brotos emitidos. Resultados esses semelhantes aos obtidos por NADHA e colaboradores (2012) com a espécies Guadua angustifolia, em que a estreptomicina foi eficaz na redução do crescimento bacteriano em culturas de tecidos de bambu para concentração de $(15 \mu \mathrm{g} / \mathrm{ml})$, onde a taxa de multiplicação de brotos tratados com antibiótico foi semelhante ao de plantas não tratadas com antibiótico.

A média de emissão de brotos dos 18 explantes de $B$. oldhamii em meio semissólido foi de 3,83. Quando transferidos para meio líquido a média de brotos subiu para 6,94 sendo essa diferença significativa $(t=3,4185 ; p=0,0017)$. A altura média dos brotos de $B$. oldhamii em meio semissólido foi de $2,93 \mathrm{~cm}$, quando transferidos para meio líquido a média de altura aumentou para $4,42 \mathrm{~cm}$, sendo essa diferença significativa $(t=4,0036 ; p=0,0003)$. Esse resultado se assemelha aos obtidos por Sheeba e colaboradores (2005), onde a média de emissão de brotos de Bambusa wamin em meio líquido $(3,89)$ foi superior à média de brotos no meio semissólido $(2,71)$.

Da mesma forma que os resultados podem variar em relação às espécies testadas, o tipo de meio, semissólido ou líquido, também é outra importante variável a ser considerada no estabelecimento das espécies de bambu in vitro. Meios líquidos possuem a vantagem de estar em contato mais permanente com o explante, garantindo absorção mais eficiente dos nutrientes e controle mais efetivo de contaminações no caso do uso de antibióticos. Apesar das vantagens dos meios líquidos, a utilização é limitada devido à oxigenação reduzida dos explantes e a possível ocorrência de hiperhidricidade dos tecidos, problema que ocorre pelo excesso de umidade durante 0 desenvolvimento do explante in vitro (GRATTAPAGLIA \& MACHADO, 1998). Entretanto, o problema da hiperhidricidade não foi detectado nas novas brotações de $B$. oldhamii em meio líquido.

Ocorreu contaminação microbiana em todos os tratamentos, podendo estar relacionada com a presença de microrganismos endofíticos que não são eliminados durante o processo de assepsia superficial, já que estão presentes no interior dos tecidos vegetais. Embora possam ser benéficos para a planta na natureza, estes mesmos organismos endofíticos tornam-se um dos principais limitadores no processo de micropropagação, especificamente, no início da fase de multiplicação. Muitas vezes contaminações bacterianas endofíticas surgem no meio de cultura somente após seis ou sete repicagens (ANDRADE, 2002). Estas contaminações impedem o desenvolvimento do explante in vitro, não somente pela competição com os nutrientes do meio de cultura, mas, principalmente, pela liberação de compostos tóxicos no meio durante o desenvolvimento de fungos e bactérias (SMITH, 2000).

Dentre os 26 explantes de $D$. asper, 17 apresentaram contaminação fúngica e 19 contaminação bacteriana. Dos 38 explantes de $B$. oldhamii submetidos ao tratamento de descontaminação sem antibiótico, 1 apresentou contaminação fúngica e 21 apresentaram contaminação bacteriana. Dos 38 explantes de $B$. oldhamii submetidos ao tratamento de descontaminação com estreptomicina 12 apresentaram contaminação fúngica e 8 contaminação bacteriana (Tabela 2). 
TABELA 2 Relação das taxas de contaminação microbiana em espécies de bambu submetidas a diferentes tratamentos de assepsia.

\begin{tabular}{ccccc}
\hline \multirow{2}{*}{ Espécie } & Explantes & \multicolumn{2}{c}{ Contaminação } & \multirow{2}{*}{ Não } \\
\cline { 3 - 4 } & Fúngica & Bacteriana & contaminados \\
\hline $\begin{array}{c}\text { Dendrocalamus } \\
\text { asper }\end{array}$ & 26 & $17(65,38 \%)$ & $19(73,07 \%)$ & $7(26,92 \%)$ \\
$\begin{array}{c}\text { (Descontaminação } \\
\text { sem antibiótico) }\end{array}$ & & & & \\
$\begin{array}{c}\text { Bambusa oldhamii } \\
\text { (Descontaminação } \\
\text { sem antibiótico) }\end{array}$ & 38 & $1(2,63 \%)$ & $21(55,26 \%)$ & $16(42,10 \%)$ \\
$\begin{array}{c}\text { Bambusa oldhamii } \\
\text { (Descontaminação } \\
\text { com antibiótico) }\end{array}$ & 38 & $12(31,57 \%)$ & $8(21,05 \%)$ & $16(42,10 \%)$ \\
\hline
\end{tabular}

Comparando a taxa de contaminação fúngica de explantes de $D$. asper e $B$. oldhamii, ambos submetidos ao tratamento de assepsia sem antibiótico, observou-se que $D$. asper apresentou taxa de contaminação fúngica $(65,38 \%)$ muito maior que os explantes de $B$. oldhamii $(2,63 \%)$. A porcentagem de contaminação bacteriana foi de $73,07 \%$ para $D$. asper e $55,26 \%$ para $B$. oldhamii (Figura 3 ).

FIGURA 3. Dendrocalamus asper após 12 dias de cultivo em meio MS semissólido suplementado com BAP e KIN, sob fotoperíodo de 16 horas e temperatura de $25 \pm 1^{\circ} \mathrm{C}$, apresentando contaminação fúngica (seta preta) e bacteriana (seta vermelha). Fonte da figura: primeiro autor.

Pode-se observar que houve uma queda de $38,09 \%$ da ocorrência de bactérias nas repetições com o uso de antibiótico no processo de assepsia quando comparados ao processo de assepsia sem antibiótico. Houve também um aumento da contaminação fúngica no tratamento com estreptomicina de $28,94 \%$ A 
estreptomicina se mostrou eficaz na redução da contaminação bacteriana. Embora o seu uso não interfira no número de brotos emitidos, novos experimentos devem ser feitos para verificar o aumento da contaminação fúngica constatados neste experimento.

O aumento da contaminação fúngica no tratamento com antibiótico pode ter sido influenciado pelo período em que a coleta do material foi realizada. SINGH e colaboradores (2011) relataram que o período de coleta de material de Dendrocalamus asper influenciou na taxa de contaminação dos explantes in vitro, sendo que nos meses de fevereiro a abril foi de $8,7 \%$, em maio e junho $14 \%$ e setembro a dezembro chegou a $50 \%$.

Estudos mais detalhados abordando o isolamento, caracterização e controle de bactérias e fungos endofíticos presentes nos explantes destas duas espécies são fundamentais para a progressão dos experimentos, visto que a grande ocorrência de contaminação in vitro impede a continuidade dos testes.

\section{CONCLUSÕES}

No estabelecimento in vitro a estreptomicina foi eficaz na redução da contaminação bacteriana em Bambusa oldhamii, não interferindo na quantidade de novos brotos emitidos.

Bambusa oldhamii submetido às mesmas condições de cultivo que Dendrocalamus asper emite em média o dobro de brotos.

Bambusa oldhamii cultivado inicialmente em meio semissólido quando transferido para meio líquido apresenta aumento significativo no crescimento e emissão de novos brotos.

\section{AGRADECIMENTOS}

Ao CNPq pelo auxílio financeiro.

\section{REFERÊNCIAS}

ALMEIDA, R. A; SETTE, C.R.; RIBEIRO, D.G.; AUXILIADORA, G.F.; FERREIRA, L.D.B.; VERA, R.; SIBOV, S.T. Chamada MCTI/AÇÃO TRANSVERSAL/CNPq N.․ 66. Projeto: Estruturação de uma Rede de Pesquisa e Desenvolvimento da Cultura do Bambu no Estado de Goiás, 2013, 85 p.

ANDRADE, S.R.M. Princípios da Cultura de Tecidos Vegetais. Boletim de Pesquisa e Desenvolvimento - Documentos / Embrapa Cerrados. 1ㄹ. ed. Planaltina-DF, $n$. 58, p.16, 2002.

ARSHAD, S.M..; KUMAR, A.; BHATNAGAR, S.K. Micropropagation of Bambusa wamin through shoot proliferation of mature nodal explants. Journal of Biological Research, v. 3, n. 14, p. 59-66, 2005.

CALDAS, L.S.; HARIDASSAN, P.; FERREIRA, M.E. Meios nutritivos. In: TORRES, A. C. CALDAS, L. S. BUSO, J. A. (Org.). Cultura de tecidos e transformação genética de plantas. Brasília: Embrapa-CNPH, v. 1, cap. 3, p. 87-117.1998. 
COMPANT, S.; CLEMENT, C.; SESSITSCH, A. Plant growth-promoting bacteria in the rhizo- and endosphere of plants: their role in colonization, mechanisms involved and prospects for utilization. Soil Biology \& Biochemistry, v. 42, n. 5, p. 669-678, 2010.

CORREIA, V.C. Produção e caracterização de polpa organossolve de bambu para reforço de matrizes cimentícias. 2011. 121f. Dissertação (Mestrado em Zootecnia) - Faculdade de Zootecnia e Engenharia de Alimentos, Universidade de São Paulo, Pirassununga, 2011.

DEVI, W.S.; SHARMA, G.J. In vitro propagation of Arundinaria callosa Munro - an Edible Bamboo from nodal explants of mature plants. The Open Plant Science Journal, v.3, p. 35-39, 2009.

FRANÇA, C.D. Potencialidades de espécies de Bambu para estabilidade de encostas e áreas degradadas em solos de cerrado. 2011. 81f. Dissertação (Mestrado em Agronomia) - Faculdade de Agronomia e Medicina Veterinária, Universidade de Brasília, Brasília, 2011.

GRATTAPAGLIA, D.; MACHADO, M.A. Micropropagação. In: TORRES; A.C.; CALDAS, L.S.; BUSO, J.A. (eds.). Cultura de tecidos e transformação genética de plantas. Brasília: Embrapa-SPI: Embrapa-CNPH, v. 1, p. 183-260, 1998.

LIN, C.S.; KALPANA, K.; CHANG, WC.; LIN, NS. Improving Mutiple Shoot Proliferation in bamboo Mosaic virus-free Bambusa oldhamii Munro propagation by liquid culture. HortScience, v.42, n. 5, p.1243-1246, 2007.

MOSHYNETS, O.V.; BRUNET, J.; POTTERS, G. Identification of endophytic bacteria in Phyllostachys sp. and Fargesia sp. Bamboo Science and Culture: The Journal of the American Bamboo Society, v. 25, n. 1, p. 19-26, 2012.

MURASHIGE, T.; SKOOG, F. A Revised medium for rapid growth and bio assays with Tobacco tissue cultures. Physiologia Plantarum, v. 15, n. 3, p. 473-497, 1962.

NADHA, H.K.; SALWAN, R.; KASANA, R.C.; ANAND, M. SOOD A. Identification and elimination of bacterial contamination during in vitro propagation of Guadua angustifolia Kunth. Pharmacognosy Magazine, v. 8, n. 30, p. 93-97, 2012.

SALGADO, A.L.B. Bambu com sal: aqui e agora, lá e então. Campinas: Amaro Comunicação, $1^{\text {a }}$ ed. 2014. 352p.

SINGH, S.R.; DALAL, S.; SINGH R.; DHAWAN, A.K.; KALIA, R.K. Micropropagation of Dendrocalamus asper (Schultes f.) Backer ex Heyne: an exotic edible bamboo. Journal of Plant Biochemistry and biotechnology. v. 22, n.2, p. 220-228, 2011.

SCHERWINSKI-PEREIRA, J. E. Contaminações microbianas na cultura de células, tecidos e órgãos de plantas. Brasília, DF: Embrapa informação tecnológica. 2010. 446 p. 
SMITH, J. Micro-propagation of the Gymea Lily: a report for the Rural Industries Research and Development Corporation. Kingston: Rural Industries Research \& Development Corpopation, 2000. 59 p.

THOMAS, P.; KUMARI, S.; SWARNA, G.K.; PRAKASH, D.P.; DINESH, M.R. Ubiquitous presence of fastidious endophytic bactéria in field shoots and indexnegative apparently clean shoot-tip cultures of papaya. Cell Biology and Morphogenesis, v.26, n. 9, p. 1491-1499, 2007. 